\title{
Effect of Blood Sampling and Administration of ACTH on Cortisol and Progesterone Levels in Ovariectomized Zebu Cows (Bos indicus)
}

\author{
By J.M. Bolaños ${ }^{*}$, J.R. Molina ${ }^{2}$ and M. Forsberg ${ }^{3}$ \\ ${ }^{1}$ Ministry of Agriculture, and ${ }^{2}$ Department of Animal Science, University of Costa Rica, San José, Costa Rica, \\ and ${ }^{3}$ Department of Clinical Chemistry, Faculty of Veterinary Medicine, Swedish University of Agricultural Sci- \\ ences, Sweden.
}

\begin{abstract}
Bolaños, J.M., J.R. Molina and M. Forsberg: Effect of blood sampling and administration of ACTH on cortisol and progesterone levels in ovariectomized zebu cows (Bos indicus). Acta vet. scand. 1997, 38, 1-7. - Four zebu cows were bilaterally ovariectomized through lateral laparotomy. Three months after ovariectomy, blood samples were collected by jugular venipuncture daily for 5 consecutive days prior to a single injection of ACTH to establish baseline concentrations of cortisol and progesterone. Baseline concentrations of cortisol and progesterone were $31 \pm 5 \mathrm{nmol} / \mathrm{L}$ and $0.3 \pm 0.01$ $\mathrm{nmol} / \mathrm{L}$, respectively. On the day of ACTH treatment the cows were allowed to rest for $2 \mathrm{~h}$ to reduce the stress of cannulation before the sampling period started. Blood samples were collected every $30 \mathrm{~min}$ from $2 \mathrm{~h}$ before until $2 \mathrm{~h}$ after the injection of $6 \mu \mathrm{g}$ ACTH and hourly between 2-6 $\mathrm{h}$ after ACTH injection. A significant increase was observed in cortisol secretion from $90 \mathrm{~min}$ before until $120 \mathrm{~min}$ after ACTH injection. No significant increase was observed in progesterone secretion before ACTH injection. After ACTH injection progesterone was significantly elevated for $120 \mathrm{~min}$. Four weeks after the ACTH treatment the cows were cannulated again and blood samples were collected following the same bleeding schedule used during the ACTH experiment. Instead of ACTH a saline injection was given via the catheter. A significant increase in cortisol concentration was recorded $90 \mathrm{~min}$ before saline injection. This increase was not accompanied by an elevation in progesterone concentration. No significant changes were observed in cortisol and progesterone levels after saline injection. When cortisol was added to a plasma pool having a progesterone concentration of $0.3 \mathrm{nmol} / \mathrm{L}$ and a cortisol concentration of $25.4 \mathrm{nmol} / \mathrm{L}$ and assayed for progesterone in 2 different assays no increase in progesterone concentration was observed. We conclude that the adrenal glands can be an extra-ovarian source of progesterone during stress in Zebu cows.
\end{abstract}

ACTH.

\section{Introduction}

Several stress conditions alter or depress reproductive performance in mammals (Levine \& Urshin 1991, Rivier \& Rivest 1991, Rivest \&

* Current address: Dept. of Clinical Chemistry, Swedish University of Agricultural Sciences, P.O. Box 7038, S-750 07 Uppsala, Sweden.
Rivier 1995). In response to the stress stimuli glucocorticoids are secreted from the adrenal cortex mediated by CRF (corticotrophin-releasing factor) from hypothalamus and with subsequent ACTH release from the anterior pituitary gland.

Cortisol is the predominant glucocorticoid in 
bovine blood and has been used as a reliable endpoint to determine the response to stress and disease of the adrenal cortex (Venkataseshu \& Estergren 1970). Stoebel \& Moberg (1982) reported that adrenal activity increases in cows submitted to stress with an increase in circulating cortisol levels.

Progesterone is known to be secreted by the adrenal glands of rats (Resko 1969, Fajer et al. 1971), ewes (Green \& More 1977), cows (Gwasdauskas et al. 1972, Wagner et al. 1972), red deer (Jopson et al. 1990), white-tailed deer (Wesson et al. 1979, Plotka et al. 1983) and fallow deer (Asher et al. 1989). Watson \& Munro (1984) showed that administration of increasing doses of ACTH to ovariectomized cows (Bos taurus) produced a dose-response curve of progesterone in peripheral blood. The authors concluded that progesterone was produced by the adrenal glands in response to low doses of ACTH, similar to natural stress, and was of sufficient magnitude to interfere with reproduction and influence fertility.

In the zebu cow, the level of stress reached when animals are submitted to intense management or experimental procedures is notably high. Furthermore, high ambient temperature has been reported to influence the length of the oestrus cycle and reduce the intensity of oestrus signs (Abilay et al. 1975, Hein \& Allrich 1992). Lamothe-Zavaleta et al. $(1991 \mathrm{a}, \mathrm{b})$ reported that cortisol secretion was elevated in zebu cows during the rainy season and that progesterone secretion in the beginning of the luteal phase was higher during the rainy season, with high ambient temperature, as compared to the dry season.

In a post-partum study performed in zebu cows in Costa Rica, unexpected fluctuations in progesterone after parturition were observed (Bolaños \& Molina 1994) indicating that either progesterone or some other compound produced in response to the stress of handling and blood sampling was measured in the progesterone assay.

The objective of the present study was to quantify the progesterone response to blood sampling and administration of synthetic ACTH in ovariectomized zebu cows, evaluating the adrenal glands as a possible secondary source of progesterone and the potential influence of acute stress on reproductive function in Bos indicus cattle.

\section{Materials and Methods}

\section{Animals and experimental design}

The study was carried out in the humid tropical area of Costa Rica in the region of San Carlos, Alajuela located at latitude $9^{\circ} 22^{\prime} \mathrm{N}, 84^{\circ} 33^{\prime} \mathrm{W}$ and $75 \mathrm{~m}$ above sea level. The average yearly rainfall is $3100 \mathrm{~mm}$ and relative humidity $82.5 \%$ with an annual mean temperature of $27.3^{\circ} \mathrm{C}$.

Four zebu cows, aged $60 \pm 0.9$ (mean \pm SEM) months and weighing $432 \pm 26 \mathrm{~kg}$, were bilaterally ovariectomized by lateral laparotomy. The cows were clinically healthy when selected for the experiment and were carefully monitored during the experimental period. The cows grazed on natural pastures with free access to water. No supplemental feed was offered during the experimental period.

Three months after ovariectomy blood samples were collected into heparinized Monoject tubes (Shewood Medicals, St. Louis, MO, USA) by jugular venipuncture daily for 5 consecutive days prior to the injection of ACTH to establish a baseline for cortisol and progesterone. Plasma was immediately separated by centrifugation and stored in plastic cryovials (Cryoware, Nalgene Company, Rochester MA, USA) at $-20^{\circ} \mathrm{C}$ until assayed.

On the day of ACTH treatment animals were fitted with an indwelling jugular catheter without anaesthesia at 7:30 am. After catheterization the cows were allowed to rest for $2 \mathrm{~h}$ to re- 


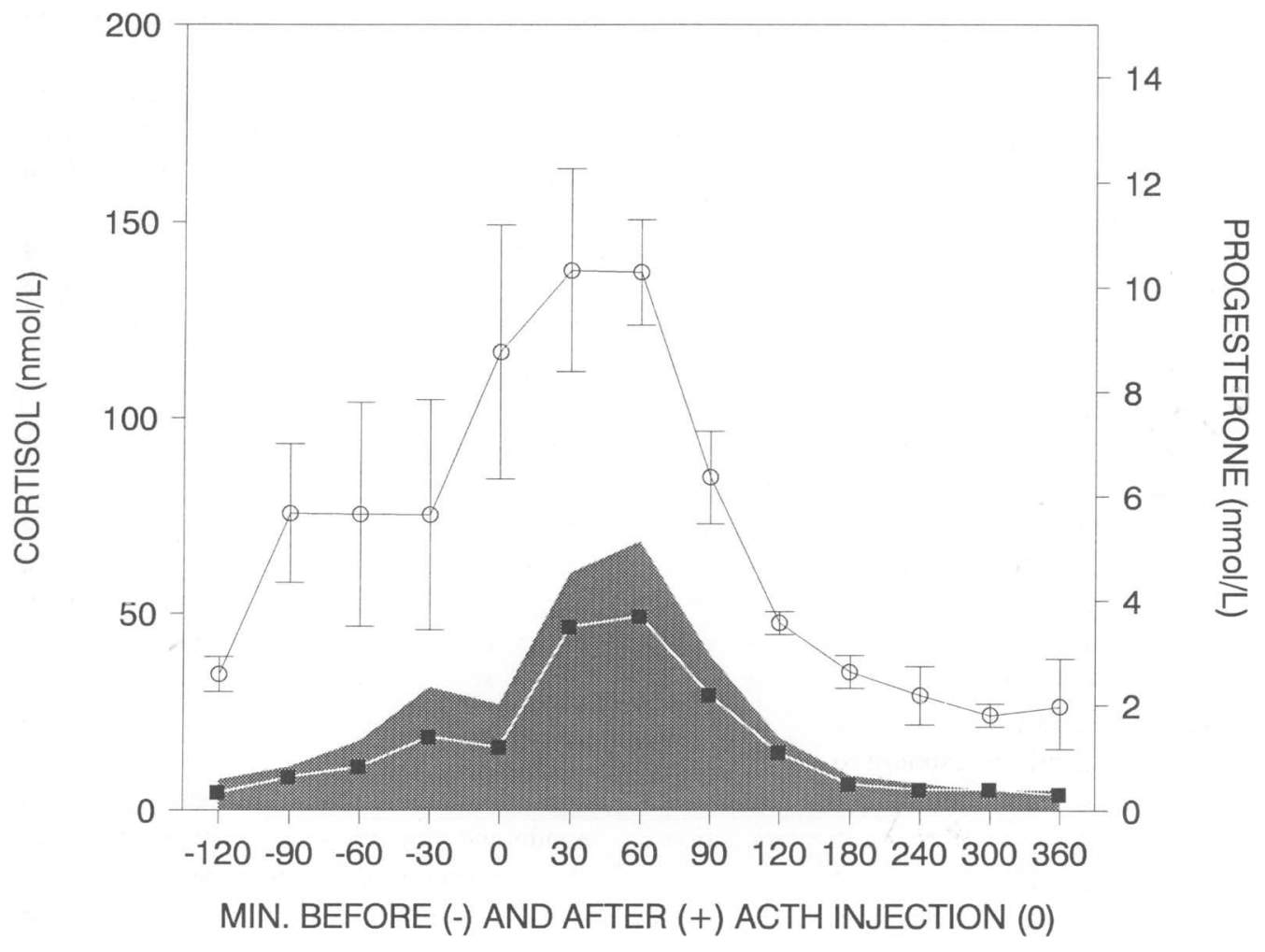

Figure 1. Temporal changes in plasma concentrations of cortisol $(O)$ and progesterone $(\square)($ mean $\pm S E M)$ before and after ACTH injection in 4 Zebu cows. The shaded area shows the maximal concentration of progesterone. The intravenous injection of $\mathrm{ACTH}$ was given directly after the blood sample at time 0 .

duce the stress of cannulation, and then the sampling period started. Blood samples were collected every $30 \mathrm{~min}$ from $2 \mathrm{~h}$ before until 2 $\mathrm{h}$ after an intravenous injection of $6 \mu \mathrm{g} \mathrm{ACTH}$ (Synacthen Depot, CIBA-GEIGY, Basile, Switzerland; Alam et al. 1986, Van der Kolk \& Breukink 1991) and hourly between 2-6 h after ACTH injection. The ACTH injection was given via the jugular catheter after the fifth blood sample.

Four weeks after the ACTH treatment the cows were cannulated again and blood samples were collected following the same bleeding schedule used during the ACTH experiment. Instead of
ACTH a saline injection was given via the catheter.

\section{Hormone assays}

Progesterone was determined by a Coat-ACount DPC kit (Diagnostic Products Corporation, Los Angeles, CA, USA). Serial dilutions of bovine plasma with high concentrations of progesterone produced inhibition curves parallel to the standard curve. The sensitivity of the assay was $0.1 \mathrm{nmol} / \mathrm{L}$. According to the manufacturer the antiserum shows no cross-reactivity with cortisol. The intra-assay coefficients of variation for 3 control samples (low, 2.3 


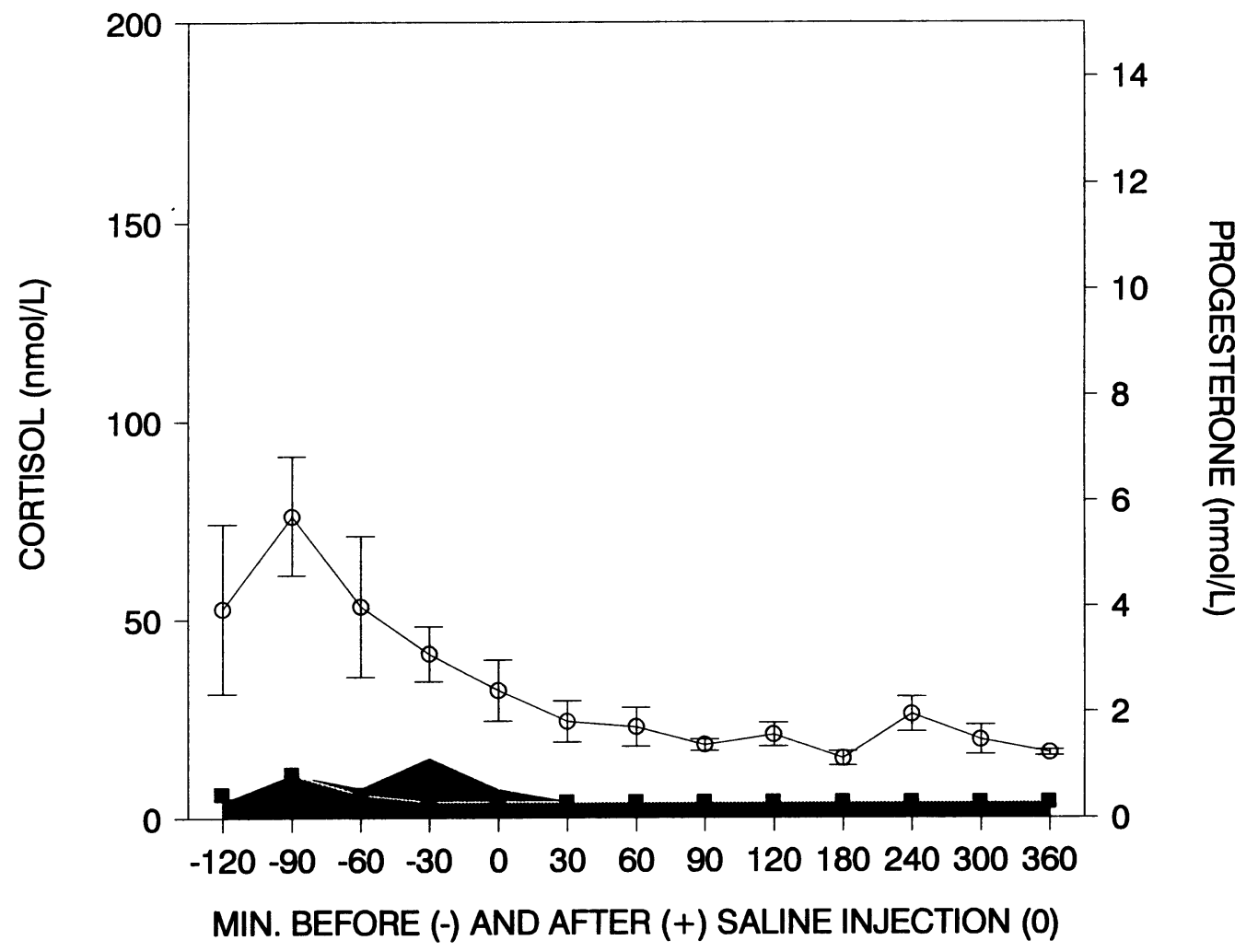

Figure 2. Temporal changes in plasma concentrations of cortisol (O) and progesterone ( $\square)($ mean \pm SEM) before and after saline injection in $4 \mathrm{Zebu}$ cows. The shaded area shows the maximal concentration of progesterone. The intravenous injection of saline was given directly after the blood sample at time 0 .

$\mathrm{nmol} / \mathrm{L}$; medium $25.7 \mathrm{nmol} / \mathrm{L}$ and high 74.2 $\mathrm{nmol} / \mathrm{L}$ ) assayed in duplicates in 20 assays were $10.6 \%, 4.7 \%$ and $7.1 \%$, respectively. The corresponding inter-assay coefficients of variation were $8.9 \%, 10.1 \%$ and $13.3 \%$.

Cortisol was determined by a Coat-A-Count, solid phase radio immunoassay kit (Diagnostic Products Corporation, Los Angeles CA, USA). The detection limit of the assay was $5.5 \mathrm{nmol} / \mathrm{L}$. According to the manufacturer the antiserum shows low cross-reactivity with progesterone $(0.15 \%)$. Quality control samples containing endogenous cortisol were assayed in duplicates at the beginning and end of each assay. The intra-assay variation was between $2.2 \%$ and $6.3 \%$. The inter-assay coefficient of variation was between $3.8 \%$ and $5.2 \%$.

To investigate the degree of cross-reactivity of cortisol with the Coat-A-Count progesterone antibody $0,62.5,125,187.5$, and $250 \mathrm{nmol} / \mathrm{L}$ of cortisol were added to a zebu plasma pool.

\section{Statistical methods}

Calibration curves, intra-assay and inter-assay coefficients of variation were calculated using procedures available in the Multicalc System (Wallac, Turku, Finland). The data were analysed by analysis of variance (Statistica, Stat- 


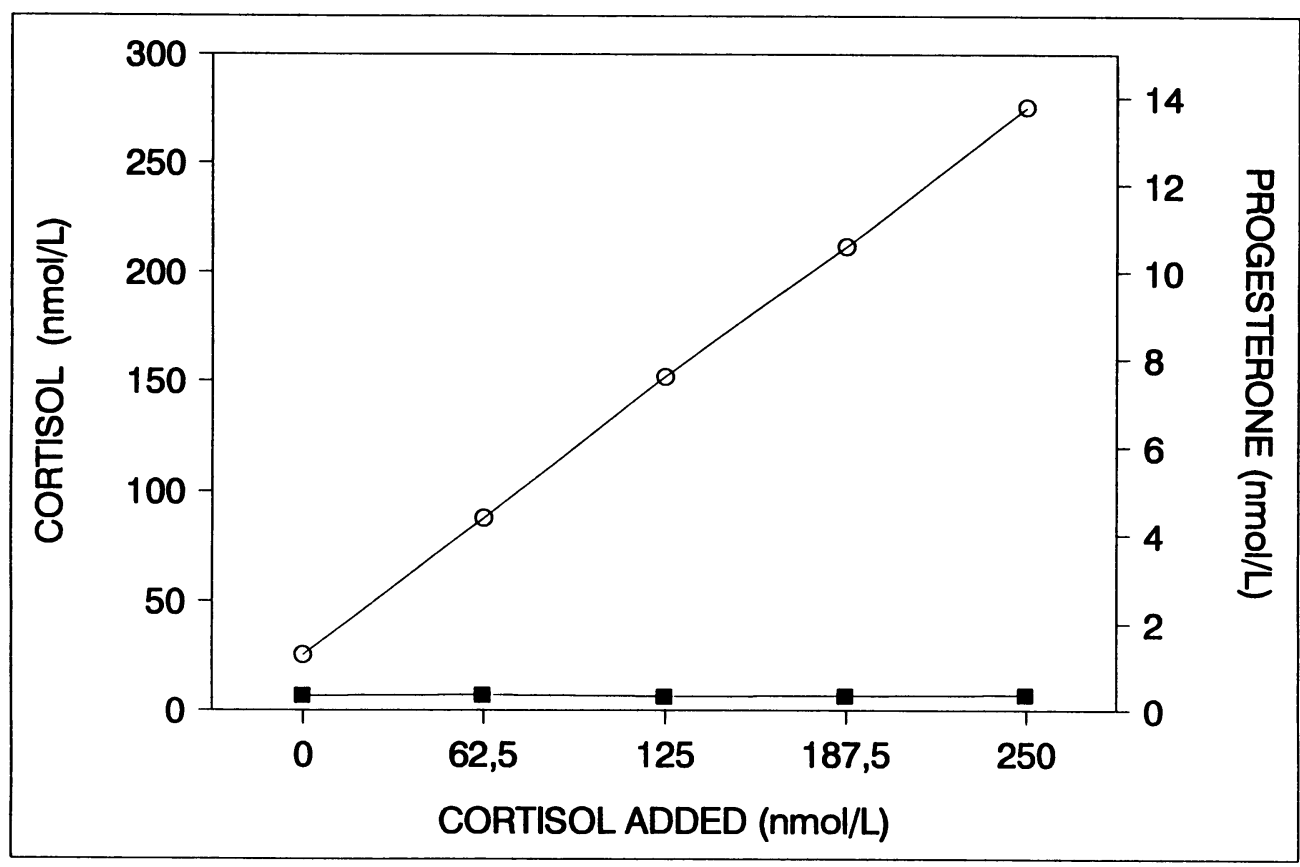

Figure 3. Concentrations of cortisol and progesterone measured in a pool of zebu plasma after addition of increasing concentrations of cortisol $(62.5,125,187.5$ and $250 \mathrm{nmol} / \mathrm{L})$. The initial concentration in the pool was $0.3 \mathrm{nmol} / \mathrm{L}$ progesterone and $25.4 \mathrm{nmol} / \mathrm{L}$ cortisol.

Soft Inc., Tulsa, OK, U.S.A). Within-treatment group comparisons were made by the LSD-test. All statistical tests having a $\mathrm{p}<0.05$ were considered significant. Results are expressed as mean \pm SEM.

\section{Results}

Baseline concentrations of cortisol and progesterone were $31 \pm 5 \mathrm{nmol} / \mathrm{L}$ and $0.3 \pm 0.01$ $\mathrm{nmol} / \mathrm{L}$, respectively. A significant increase was observed in cortisol secretion from $90 \mathrm{~min}$ before until 120 after ACTH injection. No significant increase was observed in progesterone secretion before ACTH injection. After ACTH injection progesterone was significantly elevated for $120 \mathrm{~min}$ (Fig. 1).

A significant increase in cortisol concentration was recorded $90 \mathrm{~min}$ before saline injection.
This increase was not accompanied by an elevation in progesterone concentration. No significant changes were observed in cortisol and progesterone levels after saline injection (Fig. 2).

When cortisol was added (up to a $250 \mathrm{nmol} / \mathrm{L}$ ) to a pool of zebu plasma having a progesterone concentration of $0.3 \mathrm{nmol} / \mathrm{L}$ and cortisol concentration of $25.4 \mathrm{nmol} / \mathrm{L}$ and assayed for progesterone, no increase in progesterone concentration was observed as shown in Fig. 3.

\section{Discussion}

It is evident from this study that the stress of blood sampling can produce an increase in cortisol levels in zebu cows. Similar results have been reported by Alam \& Dobson (1986) and Alam et al. (1986) who observed that not only the insertion of the jugular catheter produced a 
stress response in the cow (Bos taurus). Simple manipulation of the uterus, intramuscular or intravenous injections as well as blood sampling by venipuncture also produced increments in cortisol levels with return to baseline after 1 to $3 \mathrm{~h}$.

After ACTH injection there was a concomitant increase in measurable progesterone, assayed with the Coat-A-Count procedure, correlating with the pattern of cortisol secretion. When facing these results we decided to repeat measurements of all samples in another progesterone assay (Amerlite, Kodak Clinical Diagnostics Ltd. UK) previously validated for bovine plasma (Duchens et al. 1995). The same progesterone pattern was reproduced, but mean levels were consistently lower $(r=0.88$; Progesterone $($ Coat-A-Count $)=0.7+1.3 \times$ Progesterone (Amerlite)). However, cortisol itself is not cross-reacting with the progesterone antibodies. The manufacturers of the 2 kits report low or undetectable cross-reactivities to cortisol of their progesterone antibodies. We could also confirm this information since cortisol added to plasma samples did not produce changes in progesterone concentrations, indicating that either progesterone of extra-ovarian origin or some other steroid of structural similarity is being measured in both progesterone assays.

Our results show that stress is a factor that must be considered when reproduction of the zebu cow is studied. The adrenal glands may be an extra-ovarian source of progesterone. Such extra-ovarian secretion of progesterone could influence the interpretation of results in investigations of ovarian function in Bos indicus cattle.

\section{Acknowledgements}

We are grateful to Dr. R. Toribio for collaborating in the field work and Instituto Tecnológico de Costa Rica for providing the animals. Financial assistance was provided by the Ministerio de Agricultura y Ganaderia, Costa Rica and the Swedish Agency for Research in Developing Countries (SAREC).

\section{References}

Abilay TA, Johnson HD, Madan M: Influence of environmental heat on peripheral plasma progesterone and cortisol during the bovine estrous cycle. J Dairy Sci. 1975, 58, 1836-1840.

Alam MGS, Dobson H: Effect of various veterinary procedures on plasma concentrations of cortisol, luteinizing hormone and prostaglandin F2Alpha metabolite in the cow. Vet. Rec. 1986, 118, 7-10.

Alam MGS, Dobson H, Fizpatrick RJ: Endocrine response to different doses of ACTH in cows. Br. vet. J. 1986, 142, 239-245.

Asher GW, Peterson AJ, Duganizich D: Adrenal and ovarian sources of progesterone secretion in young female fallow deer, Dama dama. J. Reprod. Fert. 1989, 85, 667-675.

Bolaños JM, Molina JR: Resumption of ovarian activity in bos indicus cows following parturition. Ciencias Veterinarias (Costa Rica) 1994, 15, 324330.

Duchens M, Maciel M, Gustafsson H, Forsberg M, Rodriguez-Martinez H, Edqvist L-E: Influence of perioestrous suprabasal progesterone levels on cycle length, oestrus behaviour and ovulation in heifers. Anim. Reprod. Sci. 1995, 39, 171-182.

Fajer AB, Holzbauer M, Newport HM: The contribution of the adrenal gland to the total amount of progesterone produced in the female rat. J. Physiol. Lond. 1971, 214, 115-126.

Green D, Moor RM: The influence of anaesthesia on the concentration of progesterone and cortisol in peripheral plasma of sheep. Res. vet. Sci. 1977, 22, 122-123.

Gwazdauskas FC, Thatcher WW, Wilcox CJ: Adrenocorticotropin alteration of bovine peripheral plasma concentrations of cortisol, corticosterone and progesterone. J. Dairy Sci. 1972, 55, 1165-1169.

Hein $K G$, Allrich RD: Influence of exogenous adrenocorticotropic hormone on estrous behaviour in cattle. J. Anim. Sci. 1992, 70, 243-247.

Jopson NB, Fisher MW, Suttie JM: Plasma progesterone concentrations in cycling and ovariectomized red deer hinds: the effect of progesterone supplementation and adrenal stimulation. Anim. Reprod. Sci. 1990, 23, 61-73.

Lamothe-Zavaleta C, Fredriksson G, Kindahl H: Reproductive performance of Zebu cattle in Mexico.1 Sexual behaviour and seasonal influence on estrous cyclicity. Theriogenology 1991a, 36, 887896.

Lamothe-Zavaleta C, Fredriksson G, Madej A: Reproductive performance of zebu cattle in Mexico. 
2 . Seasonal influence on the levels of progesterone, oestradiol $17-\beta$, cortisol and LH during the estrous cycle. Theriogenology 1991b, 36, 897913.

Levine $S$, Urshin H: What is stress? In: Brown MR, Koob G, Rivier C (eds): Stress: Neurobiology and Neuroendocrinology. Macel Dekker Inc, New York 1991, 1, 3-21.

Plotka ED, Seal US, Verme LJ, Ozoga JJ: The adrenal gland in the white-tailed deer: a significant source of progesterone. J. Wildl. Manage. 1983, 47, 3844.

Resko JA: Endocrine control of adrenal progesterone secretion in the ovariectomized rat. Science NY 1969, 164, 70.

Rivest $S$, Rivier $C$ : The role of corticotrophin-releasing factor and interleukin-1 in the regulation of neurons controlling reproductive functions. Endocrine Reviews 1995, 16, 177-199.

Rivier $C$, Rivest $S$ : Effect of stress on the activity of the hypothalamic-pituitary-gonadal axis: peripheral and central mechanisms. Biol. Reprod. 1991, 45, 523-532.

Stoebel DP, Moberg GP: Effect of adrenocorticotropin and cortisol on luteinizing hormone surge and estrous behaviour in cows. J. Dairy Sci. 1982, 65, 1016-1024.

Van der Kolk JH, Breukink HJ: Adrenocortical function testing in dairy cows and its effect on milk yield. The Vet. Q. 1991, 13, 144-147.

Venkataseshu GK, Estergreen VL: Cortisol and corticosterone in bovine plasma and the effect of adrenocorticotropin. J. Dairy. Sci. 1970, 53, 480483.

Wagner WC, Strohbehn RE, Harris PA: ACTH, corticoids and luteal function in heifers. J. Anim. Sci. 1972, 35, 789-793.

Watson ED, Munro CD: Adrenal progesterone production in the cow. Br. vet. J. 1984, 140, 300-306.

Wesson JA, Scanlon PF, Kirkpatrick RL, Mosby HS,
Butcher RL: Influence of chemical immobilization and physical restraint on steroid hormone levels in blood of white-tailed deer. Can. J. Zool. 1979, 57, 768-776.

\section{Sammandrag \\ Effekt av blodprovstagning och ACTH injektion på blodkoncentrationerna av kortisol och progesteron hos ovarieektomerade zebu kor (Bos indicus).}

Tre månader efter att 4 zebu kor hade ovarieektomerats togs dagliga blodprover under 5 dagar för att fastställa basnivåerna i blod av kortisol och progesteron innan djuren gavs en injektion av ACTH. Basnivån för kortisol var $30 \pm 5 \mathrm{nmol} / \mathrm{L}$ och för progesteron $0.3 \pm 0.01 \mathrm{nmol} / \mathrm{L}$. Samma dag som ACTH injektionen gjordes sattes en kateter in $\mathrm{i}$ jugularvenen och djuren lämnades $\mathrm{i}$ fred under 2 timmar innan blodprovstagningen påbörjades. Blodprov samlades var 30 minut från 2 timmar före till 2 timmar efter injektion med $6 \mu \mathrm{g} \mathrm{ACTH}$ och därefter varje timme 2-6 timmar efter injektionen. Kortisolnivån var signifikant förhöjd 90 minuter före till 120 minuter efter ACTH injektionen och progesteronnivån var signifikant förhöjd efter ACTH injektionen. Fyra veckor senare upprepades proceduren med den skillnaden att istället för ACTH injicerades en koksaltlösning. En signifikant ökning av kortisolnivån sågs 90 minuter innan koksalt injektionen. Denna ökning sammanföll inte med någon signifikant stegring $\mathrm{i}$ progesteronnivån. Inga signifikanta förändringar i blodkoncentrationerna av vare sig kortisol eller progesteron kunde ses efter koksaltinjektionen. När kortisol i stigande koncentrationer tillsattes plasma och proverna analyserades med 2 olika metoder ökade kortisolkoncentrationen medan motsvarnde stegring i progesteronkoncentrationen uteblev. Experimentet styrker att progesteron inte enbart utsöndras från äggstockarna. I situationer av stress är förmodligen binjurarna en källa för progesteronproduktion.

(Received January 15, 1996; accepted September 12, 1996).

Reprints may be obtained from: M. Forsberg, Dept. of Clinical Chemistry, Swedish University of Agricultural Sciences, P.O. Box 7038, S-750 07 Uppsala, Sweden. E-mail: Mats.Forsberg@klke.sin.se, fax: +46-18309565, tel.: +46-18671613. 
